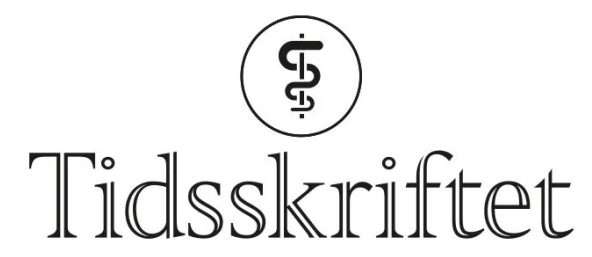

DEN NORSKE LEGEFORENING

\title{
Et apatisk barn med hallusinasjoner
}

NOE Å LARE AV

\section{INGRID ANNA TEIGEN}

iateigen@gmail.com

Institutt for klinisk og molekylær medisin

NTNU

og

Avdeling for medisinsk biokjemi og farmakologi

Haukeland universitetssjukehus

Ingrid Anna Teigen er lege i spesialisering i klinisk farmakologi og ph.d.-kandidat.

Forfatteren har fylt ut ICMJE-skjemaet og oppgir ingen interessekonflikter.

\section{JON ANDSNES BERG}

Avdeling for medisinsk biokjemi og farmakologi

Haukeland universitetssjukehus

Jon Andsnes Berg er spesialist i klinisk farmakologi og overlege.

Forfatteren har fylt ut ICMJE-skjemaet og oppgir ingen interessekonflikter.

\section{KRISTOFFER BRODWALL}

Barne- og ungdomsklinikken

Haukeland universitetssjukehus

Kristoffer Brodwall er ph.d., spesialist i barnesykdommer og overlege.

Forfatteren har fylt ut ICMJE-skjemaet og oppgir ingen interessekonflikter.

\section{Et barn i sen barnehagealder ble brakt til sykehus grunnet} uforklarlig endret adferd. Symptomene var forbigående, og flere mulige differensialdiagnoser ble vurdert. Endelig diagnose ble først fastsatt dagen etter innkomst, på bakgrunn av utvidede laboratorieprøver.

En tidligere frisk gutt $i$ sen barnehagealder ble innlagt på sykehus fordi han hadde påfallende oppførsel, var fravcerende $i$ blikket og hadde sluttet å snakke. Gutten var hyperaktiv og agitert da han ble hentet $i$ barnehagen. Barnehagen hadde hatt en ekstra lang dag med bytur og påfølgende pizzamåltid for alle barna, og foreldrene trodde først at han bare var oppspilt og overstimulert. Utover kvelden ble han imidlertid mer og mer apatisk. Han snakket ikke, og i perioder lo han uten åpenbar grunn. Foreldrene fikk ikke blikkontakt med ham og opplevde det som om han «så gjennom dem». Gangen var ustødig, men han kunne stå oppreist. Foreldrene tok ham med til legevakten, og ettersom tilstanden var såpass påfallende, ble han innlagt på sykehus for ncermere vurdering. 
Foreldrene reagerte på guttens adferd, men i begynnelsen var det uklart om han i det hele tatt hadde en medisinsk tilstand eller simpelthen var sliten etter en lang dag med mange inntrykk. På en travel legevakt kan det være utfordrende å skille pasienter som kun trenger hvile fra de som bør utredes nærmere. I dette tilfellet var manglende tale, fravær av blikkontakt og ataksi (ustøhet) nytilkomne nevrologiske symptomer som vekket bekymring og tydet på affeksjon av sentralnervesystemet.

Legevakten mistenkte soppforgiftning, fordi gutten hadde vært på tur i skogen. Andre årsaker til akutt nevrologisk påvirkning hos barn inkluderer infeksjoner som meningitt eller viral encefalitt, hodetraumer, cerebrovaskulære hendelser, elektrolyttforstyrrelser og intoksikasjon. I sjeldne tilfeller kan det også være partielle epileptiske anfall eller autoimmun encefalitt.

Da de ankom sykehuset, omkring 4-5 timer etter at foreldrene la merke til de første symptomene, hadde pasienten svcert påfallende oppførsel med manglende blikkontakt og respons på omgivelsene. Han var fullt våken og tilsynelatende uten smerter eller ubehag, men snakket ikke og lystret ingen kommandoer. Han gjorde ikke motstand mot undersøkelsene og reagerte knapt på stikket ved blodprøvetaking. Pupillene var tydelig dilaterte, med diameter på $9 \mathrm{~mm}$. Ved belysning trakk pupillene seg litt sammen, men denne reaksjonen var forsinket, og pupillene ble ikke mindre enn $6 \mathrm{~mm}$. Han var ustødig og viste utpreget falltendens.

Alle vitalparametrene var normale. Puls var 104 slag/min og blodtrykk 105/62 mm Hg.

Respirasjonsfrekvensen var 24 per minutt og $\mathrm{SpO}_{2} 99$ \% i romluft. Kroppstemperaturen ble målt til $36,6{ }^{\circ} \mathrm{C}$.

Allmenntilstanden ble videre vurdert som god. Han var ikke lyssky eller nakkestiv. Det var litt sparsomt med tarmlyder, men ellers normale funn ved undersøkelse av hjerte, lunger, buk, ører, hals og svelg. Funn ved orienterende blodprøver var også normale. Gutten fikk på urinpose, slik at man kunne ta en prøve fra den første urinen (han hadde ikke tisset siden symptomdebut før innkomst). Han ble innlagt på

Barneovervåkningen for tett overvåkning.

Kliniske og supplerende undersøkelser ga ikke holdepunkter for affeksjon av andre organer enn nervesystemet. Tilstanden var imidlertid uavklart, og for å fange opp eventuelle kliniske endringer ble han observert tett i tiden etter innkomst. Han hadde ikke feber, stigning i infeksjonsprøver, lysskyhet, nakkestivhet eller andre tegn på infeksjon, og man fant derfor ikke indikasjon for spinalpunksjon. Forgiftning var blant differensialdiagnosene. Dersom barnet hadde inntatt legemidler eller andre toksiske substanser, var det trolig gått for mange timer til at medisinsk kull eller ventrikkelskylling ville ha effekt. Slike tiltak, og i enda større grad induserte brekninger, medfører dessuten risiko for aspirasjonspneumoni og frarådes vanligvis.

Det mest dominerende symptomet var den påfallende oppførselen. Akutte psykoser kan oppstå hos barn, men er sjeldne og forekommer hovedsakelig hos barn som fra tidligere har unormal nevrologisk utvikling (1). Uttalt dilatasjon av pupillene ledet mistanken mot forgiftning, for eksempel med antikolinergika eller sympatomimetiske substanser. Det var ikke mistanke om hodetraume, han hadde ikke hatt bevissthetstap og hadde ingen symptomer på høyt intrakranialt trykk. Indikasjonen for billeddiagnostikk var derfor ikke sterk og ville ha vært teknisk utfordrende pga. manglende samarbeid. Man nøyde seg følgelig med å se an videre utvikling.

Omkring en time etter innkomst ble pasienten unders $ø$ kt på nytt. Han snakket fortsatt ikke, men begynte å vise tegn til at han forsto det som ble sagt og samarbeidet noe under unders $\varnothing k e l s e n$. Han responderte også på enkelte spørsmål i form av nikking og risting på hodet. På dette tidspunktet virket han mer interagerende med foreldrene, og han begynte å gråte.

Den spontane bedringen, uten noen spesifikk behandling, understøttet mistanken om at tilstanden skyldtes inntak av en substans som etter hvert ble metabolisert og/eller utskilt. Diagnosen var fremdeles uavklart, men den gode utviklingen gjorde at man ikke lenger var bekymret for barnets tilstand.

Omkring åtte timer etter symptomdebut (tre timer etter innkomst) kviknet pasienten ytterligere til og begynte å snakke. Han virket fremdeles sløv, men kunne gjenkjenne foreldrene og navngi objekter i rommet. I denne fasen gråt han og virket fortvilet og redd. Neste morgen var han ytterligere $i$ bedring. Pupillene var fremdeles dilaterte, men mindre uttalt enn ved innkomst (nå 7-8 mm, 4-5 $\mathrm{mm}$ ved belysning). Gjennom natten viste han tegn til hallusinasjoner, blant annet trodde han at det kom røyk fra hendene sine. På spørsmål om hva han hadde opplevd tidligere på dagen klarte han ikke å forklare seg, men i løpet av natten fortalte han til sine foreldrene at han hadde spist en gummibamse som han hadde fått av en fremmed mann $i$ 
byen. Den påfølgende dagen husket han imidlertid ingenting av denne forklaringen. Dagen etter innkomst var han i sin habitualtilstand og oppførte seg normalt. Han ble utskrevet til hjemmet og har ikke hatt noen form for sekvele i ettertid.

Symptomene, forløpet og opplysningene fra gutten ga klar mistanke om at han hadde fătt i seg et rusmiddel. Rutineanalysen for spesifikk påvisning av rusmidler i urin var imidlertid negativ.

Grunnet fortsatt mistanke om rusmiddelforgiftning ble klinisk farmakolog konferert, og det ble besluttet å gjøre et såkalt bredt substanssøk i urin- og blodprøvene. Lysergsyredietylamid (LSD) og et omdanningsprodukt, 2-okso-3-hydroksy-LSD (OH-LSD), ble påvist i urinen med denne analysemetoden. Blodprøven ble først vurdert som negativ, men etter funn i urinprøven ble det besluttet å gjøre et målrettet søk med en mer sensitiv metode, som påviste LSD og OH-LSD også i blodet. Konklusjonen ble at forgiftning med LSD var den mest sannsynlige diagnosen. Saken ble meldt til politiet.

Symptombildet med hallusinasjoner og fravær av uttalt adrenerg stimulering gjorde at vi mistenkte inntak av en hallusinogen substans heller enn et klassisk sentralstimulerende eller dempende rusmiddel. En skjematisk oversikt over typiske symptomer (hos voksne) etter inntak av et utvalg rusmidler er presentert i tabell $1(\underline{2})$. Mistanken rettet seg videre mot lavdoserte stoffer på grunn av den uvanlige formuleringen (gummibamse), herunder syntetiske cannabinoider og tryptaminer. Slike stoffer inngår ikke i rutinerepertoaret for påvisning av rusmidler i urin. Det ble derfor besluttet å gjøre bredt substanssøk, en analysemetode som i prinsippet gjør det mulig å påvise flere tusen ulike rus- og legemidler. Metoden brukes ikke rutinemessig, ettersom den er ressurskrevende og forholdsvis kostbar.

\section{Tabell 1}

Skjematisk oversikt over typiske symptomer på forgiftning med vanlige rusmidler (2).

\begin{tabular}{|c|c|c|c|}
\hline Gruppe & Rusmiddelfamilie & $\begin{array}{l}\text { Eksempler på } \\
\text { rusmidler/legemidler }\end{array}$ & $\begin{array}{l}\text { Typiske symptomer på } \\
\text { forgiftning }\end{array}$ \\
\hline \multirow[t]{2}{*}{$\begin{array}{l}\text { Stimulerende } \\
\text { rusmidler }\end{array}$} & Fenetylaminer & $\begin{array}{l}\text { Amfetamin, metamfetamin, } \\
\text { parametoksymetamfetamin } \\
\text { (PMMA), } \\
\text { metylendioksymetamfetamin } \\
\text { (MDMA) }\end{array}$ & $\begin{array}{l}\text { Mydriasis, hypertensjon, } \\
\text { takykardi, hypertermi, } \\
\text { psykomotorisk } \\
\text { hyperaktivitet, endret } \\
\text { persepsjon, } \\
\text { hallusinasjoner }\end{array}$ \\
\hline & & Kokain & $\begin{array}{l}\text { Mydriasis, hypertensjon, } \\
\text { takykardi, hypertermi, } \\
\text { psykomotorisk } \\
\text { hyperaktivitet, agitasjon, } \\
\text { arytmier, organiskemi, } \\
\text { kramper }\end{array}$ \\
\hline \multirow[t]{2}{*}{$\begin{array}{l}\text { Dempende } \\
\text { rusmidler }\end{array}$} & $\begin{array}{l}\text { Benzodiazepiner og Z- } \\
\text { hypnotika }\end{array}$ & $\begin{array}{l}\text { Klonazepam, alprazolam, } \\
\text { diazepam, oksazepam, } \\
\text { zopiklon, zolpidem }\end{array}$ & $\begin{array}{l}\text { Redusert bevissthet, } \\
\text { kognitiv treghet, snøvlet } \\
\text { tale, } \\
\text { koordinasjonsforstyrrelser, } \\
\text { forvirring, amnesi }\end{array}$ \\
\hline & Opioider & $\begin{array}{l}\text { Morfin, heroin, kodein, } \\
\text { oksykodon, buprenorfin, } \\
\text { metadon, fentanyl }\end{array}$ & $\begin{array}{l}\text { Redusert bevissthet, } \\
\text { redusert sensitivitet for } \\
\text { smerte, miose, } \\
\text { respirasjonsdepresjon, } \\
\text { redusert tarmaktivitet, } \\
\text { hypotermi, hypotensjon, } \\
\text { bradykardi }\end{array}$ \\
\hline
\end{tabular}




\begin{tabular}{|c|c|c|c|}
\hline Gruppe & Rusmiddelfamilie & $\begin{array}{l}\text { Eksempler på } \\
\text { rusmidler/legemidler }\end{array}$ & $\begin{array}{l}\text { Typiske symptomer på } \\
\text { forgiftning }\end{array}$ \\
\hline & Alkoholer & $\begin{array}{l}\text { Etanol, metanol, } \\
\text { isopropanol, etylenglykol }\end{array}$ & $\begin{array}{l}\text { Redusert bevissthet, } \\
\text { snøvlet tale, } \\
\text { koordinasjonsforstyrrelser, } \\
\text { kritikkløs adferd, amnesi, } \\
\text { forvirring, hypotensjon, } \\
\text { takykardi. } \\
\text { Metanol: synsforstyrrelser, } \\
\text { metabolsk acidose, } \\
\text { hyperventilering. } \\
\text { Etylenglykol: Metabolsk } \\
\text { acidose, hyperventilering, } \\
\text { nyresvikt, hypokalsemi. } \\
\text { Isopropanol: acetonlukt av } \\
\text { ånde, forhøyet ketonnivå } \\
\text { uten acidose }\end{array}$ \\
\hline & $\begin{array}{l}\text { Gammahydroksybutyrat } \\
\text { (GHB) }\end{array}$ & $\begin{array}{l}\text { GHB, gammabutyrolakton } \\
(\mathrm{GBL}) \text {, butandiol }\end{array}$ & $\begin{array}{l}\text { Redusert bevissthet eller } \\
\text { svingende } \\
\text { bevissthetstilstand, } \\
\text { hypotensjon, bradykardi, } \\
\text { respirasjonsdepresjon, } \\
\text { hypotermi, agitasjon og } \\
\text { hallusinasjoner. } \\
\text { Rask reversering pga. } \\
\text { hurtig metabolisme }\end{array}$ \\
\hline \multirow[t]{2}{*}{ Hallusinogener } & Cannabinoider & $\begin{array}{l}\text { Cannabis, syntetiske } \\
\text { cannabinoider }\end{array}$ & $\begin{array}{l}\text { Redusert oppmerksomhet, } \\
\text { søvnighet, forvirring, } \\
\text { hallusinasjoner, takykardi, } \\
\text { hypertensjon, konjunktival } \\
\text { injeksjon, økt appetitt }\end{array}$ \\
\hline & Tryptaminer & $\begin{array}{l}\text { Lysergsyredietylamid (LSD), } \\
\text { psilocybin, dimetyltryptamin } \\
\text { (DMT) }\end{array}$ & $\begin{array}{l}\text { Persepsjonsforstyrrelser, } \\
\text { synestesi, hallusinasjoner, } \\
\text { panikk- eller } \\
\text { fryktreaksjoner, mage- og } \\
\text { tarmsymptomer, } \\
\text { mydriasis, hypertensjon, } \\
\text { takykardi }\end{array}$ \\
\hline
\end{tabular}

\section{Diskusjon}

Erfaringen med LSD-forgiftning hos barn er begrenset og basert på spredte kasuistikker. I forbindelse med utarbeidelsen av denne kasuistikken har vi gjennomgått ti tidligere artikler appendiks ) som beskriver LSD-forgiftning hos til sammen 21 barn ((3-12). De hyppigste symptomene hos disse barna var dilaterte pupiller, hallusinasjoner/sanseillusjoner, hudrødme og bisarr adferd, inkludert påfallende bevegelser og manglende oppmerksomhet overfor omgivelsene - ikke ulikt vår pasient. Flertallet ble beskrevet som angstfulle eller utilpasse, mens bare noen få ble oppfattet som euforiske.

Dette står i motsetning til kliniske forsøk med friske voksne, der LSD hovedsakelig er rapportert å gi en behagelig rus $(\mathbf{1} 3,14$.). Negative ruseffekter ses imidlertid oftere ved høye doser $(\underline{15}, \underline{16})$. At barn som forgiftes med LSD sannsynligvis eksponeres for høyere doser per kilo kroppsvekt enn voksne, kan være en mulig forklaring på hvorfor flertallet i dette materialet opplevde negative effekter. 
Farmakokinetikken til LSD er relativt godt studert hos voksne ved doser på 100-200 $\mu$ g, hvilket tilsvarer en typisk rusdose (14.). LSD absorberes hurtig og fullstendig etter peroral administrering. Symptomer på forgiftning vil som regel debutere i løpet av 30-45 minutter, med en topp etter 1,52,5 timer. De akutte, subjektive virkningene avtar normalt etter 9-12 timer (17.), slik vi også observerte hos vår pasient. Halveringstiden er om lag tre timer, og stoffet kan som regel oppdages i blodprøver i inntil 12 timer etter inntak av én enkeltstående dose $(\underline{14}, 15,17$.). LSD metaboliseres hovedsakelig til OH-LSD, som normalt detekteres i lavere konsentrasjoner enn modersubstansen i blod. OH-LSD oppkonsentreres imidlertid i urin, der det også har et mye lengre påvisningsvindu enn LSD (opp mot fire dager), hvilket gjør det til en godt egnet markør for LSD-bruk $(\underline{17}, \underline{18})$.

I urinprøven fra vår pasient, som ble tatt omtrent åtte timer etter symptomdebut, kunne vi påvise LSD, OH-LSD og iso-LSD. Iso-LSD er ikke en LSD-metabolitt, men kan dannes ved produksjon av LSD under mindre kontrollerte forhold, slik at stoffet kan brukes som tilleggsmarkør for illegalt produsert LSD. Vi kunne ikke med sikkerhet påvise verken LSD eller OH-LSD i serum med rutinemetoden for bredt substanssøk ved vårt laboratorium. Ved å benytte et mer sensitivt instrument lot det seg imidlertid gjøre å detektere LSD også i serum. Serumkonsentrasjonen kunne ikke kvantifiseres med den aktuelle analysemetoden, men var sannsynligvis lav. Manglende samsvar mellom serumkonsentrasjon og symptomer er observert i kliniske studier av voksne, men resultatene er sprikende $(\underline{15}, \underline{18})$.

LSD er i utgangspunktet lite toksisk, men alvorlige komplikasjoner, herunder kramper, koma, respirasjonsforstyrrelser og død, er beskrevet i litteraturen $(19,20)$. I det historiske materialet vi har gjennomgått, var den høyeste oppgitte dosen 2 ooo $\mu \mathrm{g}$ LSD, hvilket tilsvarer 10-20 ordinære brukerdoser. I dette tilfellet restituerte barnet uten sekveler etter forgiftningen. LSD ble imidlertid ikke detektert i verken blod- eller urinprøver hos vedkommende, hvilket etterlater en mulighet for at forgiftningen skyldtes inntak av et annet rusmiddel eller at den reelle dosen var betydelig lavere enn den som ble oppgitt av artikkelforfatteren (11).

Det finnes ingen motgift mot LSD. Observasjon på sykehus og eventuelt symptomrettet

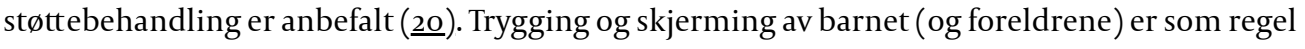
tilstrekkelig. Medisinsk kull eller ventrikkelskylling vil sjelden være indisert, grunnet hurtig absorpsjon. Hvis det er nødvendig å sedere barnet på grunn av kramper, takykardi, agitasjon, uro eller skremmende hallusinasjoner, kan et benzodiazepin forsøkes, for eksempel diazepam eller midazolam. Fentiaziner, herunder klorpromazin, som har blitt anbefalt i tidligere litteratur, frarådes, da disse kan redusere krampeterskelen (21).

Godterier, slik som gummibamser, tilsatt rusmidler har i økende grad blitt tilgjengelig på markedet. Dette gjelder spesielt USA og Canada og er trolig knyttet til legalisering av cannabisprodukter (2ㅡ). Cannabis og syntetiske cannabinoider er i større grad enn LSD assosiert med denne «formuleringen», men LSD-produkter innpakket som godteri er også lett tilgjengelig på internett. Det er beskrevet en rekke tilfeller med forgiftninger som følge av at barn har inntatt det de trodde var vanlig godteri (23).

Forgiftninger med LSD og andre hallusinogene stoffer er sjeldne hos barn og kan være utfordrende å oppdage klinisk. Dette gjelder særlig for små barn med begrenset formidlingsevne, ettersom symptomatologien ofte er uspesifikk. Bekreftende laboratorieprøver kan derfor være avgjørende diagnostiske verktøy. Vi vil råde klinikere som møter pediatriske pasienter med uforklarlige psykiske symptomer og kroppslige fenomener til å vurdere forgiftning med rusmidler som en mulig differensialdiagnose. Der det er praktisk mulig bør både blod- og urinprøver sikres ved innleggelse. En rekke rusmidler, slik som LSD, har kort halveringstid, og tid fra inntak til prøvetaking er derfor av betydning for om man detekterer substansen i pasientprøven eller ikke. I tillegg til initial rusmiddelscreening har man ved flere av de større sykehusene i Norge muligheten til å etterrekvirere bredt substanss $\varnothing \mathrm{k}$ for å avdekke forgiftning med sjeldne stoffer som ikke inngår i rutinerepertoaret for rusmiddelanalyser. Det kan også være nyttig å kontakte Giftinformasjonssentralen ved mistanke om forgiftning med ukjent substans. De kan gi råd om prøvetakning, oppfølging og behandling. Ved mistanke om soppforgiftning kan de også formidle kontakt med et laboratorium som kan undersøke ventrikkelinnhold/oppkast.

Pasientens foresatte har gitt samtykke til at artikkelen blir publisert. 
1. Israni $A V$, Kumar $S$, Hussain N. Fifteen-minute consultation: an approach to a child presenting to the emergency department with acute psychotic symptoms. Arch Dis Child Educ Pract Ed 2018; 103: 184-8.

[PubMed][CrossRef]

2. UpToDate. Adult toxicology. https://www.uptodate.com/contents/table-of-contents/emergency-medicineadult-and-pediatric/adult-toxicology Lest 7.11.2019.

3. Aleguas A, Pearson JM, Peredy TR. LSD poisoning after ingestion of contaminated beef in a family of four. Clin Toxicol 2015; 53: 339 .

4. Assmus H, Reimer F. Accidental LSD intoxication in three siblings with flashback.] Prax Kinderpsychol Kinderpsychiatr 1972; 21: 207-9. [PubMed]

5. Bähr G, Boiselle I, Kiefer B. LSD-intoxication in 9 children.] Monatsschr Kinderheilkd 1972; 120: 287-8. [PubMed]

6. Greenblatt DJ, Allen MD, Koch-Weser J et al. Accidental poisoning with psychotropic drugs in children. Am J Dis Child 1976; 130: 507-11. [PubMed]

7. Ianzito BM, Liskow B, Stewart MA. Reaction to LSD in a two-year-old child. J Pediatr 1972; 80: 643-7. [PubMed][CrossRef]

8. Johnson GD, Elmore SE, Adams FF. The "trip" of a two year old. J S C Med Assoc 1970; 66: 424-5. [PubMed]

9. Maslanka AM, Scott SK. LSD overdose in an eight-month-old boy. J Emerg Med 1992; 10: 481-3. [PubMed] [CrossRef]

10. Milman DH. An untoward reaction to accidental ingestion of LSD in a 5-year-old girl. JAMA 1967; 201: 821-5. [PubMed][CrossRef]

11. Samuelsson BO. LSD intoxication in a two-year-old child. Acta Paediatr Scand 1974; 63: 797-8. [PubMed] [CrossRef]

12. Schwartz JG, Hopkovitz AM. LSD intoxication. J Fam Pract 1988; 27: 550-1. [PubMed]

13. Carhart-Harris RL, Kaelen M, Bolstridge $M$ et al. The paradoxical psychological effects of lysergic acid diethylamide (LSD). Psychol Med 2016; 46: 1379-9o. [PubMed][CrossRef]

14. Liechti ME. Modern clinical research on LSD. Neuropsychopharmacology 2017; 42: 2114-27. [PubMed] [CrossRef]

15. Dolder PC, Schmid Y, Haschke M et al. Pharmacokinetics and concentration-effect relationship of oral LSD in humans. Int J Neuropsychopharmacol 2016; 19: pyv072. [PubMed][CrossRef]

16. Dolder PC, Schmid Y, Steuer AE et al. Pharmacokinetics and pharmacodynamics of lysergic acid diethylamide in healthy subjects. Clin Pharmacokinet 2017; 56:1219-30. [PubMed][CrossRef]

17. Passie T, Halpern JH, Stichtenoth DO et al. The pharmacology of lysergic acid diethylamide: a review. CNS Neurosci Ther 2008; 14: 295-314. [PubMed][CrossRef]

18. Libânio Osório Marta RF. Metabolism of lysergic acid diethylamide (LSD): an update. Drug Metab Rev 2019; 51:378-87. [PubMed][CrossRef]

19. Nichols DE, Grob CS. Is LSD toxic? Forensic Sci Int 2018; 284: 141-5. [PubMed][CrossRef]

20. Giftinformasjonen. LSD (lysergsyredietylamid)- behandlingsanbefaling ved forgiftning. https://www.helsebiblioteket.no/forgiftninger/rusmidler/lsd-lysergsyredietylamid-behandlingsanbefalingved-forgiftning Lest 9.7.2019.

21. Riordan M, Rylance G, Berry K. Poisoning in children 5 : rare and dangerous poisons. Arch Dis Child 2002; 87:407-10. [PubMed][CrossRef]

22. Blohm E, Sell P, Neavyn M. Cannabinoid toxicity in pediatrics. Curr Opin Pediatr 2019;31: 256-61. [PubMed] [CrossRef]

23. Vo KT, Horng H, Li K et al. Cannabis intoxication case series: The dangers of edibles containing tetrahydrocannabinol. Ann Emerg Med 2018; 71:306-13. [PubMed][CrossRef]

Publisert: 22. februar 2021. Tidsskr Nor Legeforen. DOI: 10.4045/tidsskr.20.0569

Mottatt 30.6.2020, første revisjon innsendt 9.11.2020, godkjent 19.11.2020.

Publisert under åpen tilgang CC BY-ND. Lastet ned fra tidsskriftet.no 26. april 2023. 